\title{
The Challenge of Mütterliteratur: Gender, Generation, and the Genres of German Cultural Memory
}

Katra A. Byram

ABSTRACT

Current models of German postwar memory culture often contrast an accusatory second-generation Väterliteratur with a more self-reflexive third-generation family writing. This article demonstrates that reading second-generation books about mothers in the context of historical cultural memory undermines this distinction. Ingeborg Drewitz's Gestern war heute (1978), Barbara Bronnen's Die Tochter (1982), and Helga Novak's Die Eisheiligen (1979) share key features with the post-Wende "new family novel" typified in recent scholarship. These similarities suggest that changing enactments of gender and cultural memory have allowed previously feminized experiences and memory practices to evolve into the basis for a national memory culture.

Generations and their shared horizons of historical experience have dominated the story told about Germans' postwar reckoning with National Socialism. Although Sigrid Weigel argued more than a decade ago that this obsession with generation covers over other factors inflecting individual and cultural memory, ${ }^{1}$ generational categories continue to color both public imagination and scholarly work. Common wisdom holds that the war generation silenced and repressed its guilt, the second generation rejected and roundly criticized this response, and the third generation is now pursuing a more differentiated and individualized understanding of Germans' actions and experience under the Third Reich. In literary scholarship, the second generation has been associated with the genre of Väterliteratur (father literature) of the 1970s and 1980s, in which rebelling sons and daughters indict their fathers' complicity in National Socialism after those fathers' deaths. Often, this literary reckoning has been 
read negatively, as the children's "pursuit of exoneration from responsibility"2 and as symptomatic of the generation's "depressive self-obsession, a negative narcissism, which manifests itself in the form of chronic complaining." ${ }^{3}$ The third generation, in contrast, is associated with the "new family novel," in which narrators take a reflective and nuanced approach to the history of a variety of family members. Anne Fuchs's opinion that these "memory contests" represent a "particularly productive form of cultural memory"4 aligns with Friederike Eigler's assessment of the "new generational novel" and Michaela Holdenried's and Aleida Assmann's evaluation of "the new family novel." The story of a generational shift in family writing thus sets the postwar generation's conflictive, self-righteous relationships with their parents against the third generation's self-reflexive, empathetic encounter with a more extensive genealogy of inheritance.

Recent work has challenged the idea of a genre called Väterliteratur. Julius Reidy and Mathias Brandstädter argue that the corpus is too heterogeneous to permit a unifying label, and Brandstädter rejects clear demarcations between second- and thirdgeneration writing, contending that narratological patterns and the memory practices they signal co-exist during both eras. Still, he does not deny shifting memory practices over time; rather, he argues that different patterns dominate during different eras. ${ }^{6}$ Similarly, this essay acknowledges that memory practices have changed, but insists on the heterogeneity of second-generation literature and the impossibility of distinguishing it neatly from third-generational writing. Differently than Brandstädter's book, however, it suggests that considering the influence of gender on memory practice may help us to understand both these changes and the influential view that they are driven by generational experience. Gender assumptions embedded within stories about past and present have supported the creation and persistence of generational categories. When the gendered dynamics of memory are exposed, the generational map of memory culture disintegrates.

The move from the gendered term Väterliteratur to the gender-neutral "new family novel" itself implies a change in the relationship between gender and memory culture, in literary works of Vergangenheitsbewältigung (reckoning with the past), in critical and scholarly responses to them, or in both. The contours of this transformation become visible when mother books contemporaneous with the Väterliteraturwhat I call Mütterliteratur (mother literature) here-are read within the context of cultural memory. My intention in talking about Mütterliteratur is not to coin a new generic label that contrasts with Väterliteratur and, in so doing, confirm Väterliteratur as a genre; rather, it is to point out that second-generation writing has been filtered through a gendered lens. Reading the mother books as second-generation Vergangenheitsbewältigung — changing the gendered filter-changes the color and texture of second-generation writing. It also helps to explain why the heterogeneity of writing about fathers has been so often underappreciated: gender expectations have 
screened certain elements of Väterliteratur from widespread perception. In this essay, I refer to Väterliteratur and its common reception, not to affirm the existence of a homogenous genre, but to discuss the cultural work that the genre label has done. I use Mütterliteratur not to propose a new genre, but to designate books about mothers from the "Väterliteratur" era.

Mütter- and Väterliteratur share many characteristics and concerns. Both explore the intertwined identities of parent and child during National Socialism, World War II, and their aftermath, and both address similar themes: the parents' complicity with or tolerance of National Socialism, the resulting emotional and psychological wounds within families, the parents' impact on their children's characters and lives, the interweaving of the personal and the political, and the negotiation or escape of traditional gender paradigms. At the same time, many mother books resemble thirdgeneration writing in many ways. Caroline Schaumann's characterization of mother books by daughters identifies features that are also common in descriptions of the new family novel; mother books, she writes, combine "discord and empathy, distance and understanding, as well as emotionally charged considerations on the process of transmitting memories."7 All but one of Schaumann's examples stem from the post1990 period, however, so that these similarities might also be attributed to their place in time, rather than to gender dynamics. By examining three representative mother books from the earlier era, Ingeborg Drewitz's Gestern war heute: 100 Jahre Gegenwart (Yesterday was Today: 100 Years of the Present) (1978), Barbara Bronnen's Die Tochter (The Daughter) (1980), and Helga Novak's Die Eisheiligen (The Ice Saints) (1989), and showing their similarity to works of the post-Wall era, I suggest that a mode of memory long understood as feminine provides the ground for the recent shift in memory culture. ${ }^{8}$ The "new" memory culture does not originate with the third generation; rather, it exhibits a new readiness to include experiences and memory practices historically coded as feminine.

\section{Memory, Gender, Genre, and the Postwar German Context}

Until recently, the question of gender has played a marginal role in memory studies. However, as Meike Penkwitt and Katherine Stone explain, today both gender and memory are seen as constructed and performative. ${ }^{9}$ In the more than two decades since Judith Butler's 1991 Gender Trouble, performativity has become the guiding concept of gender studies. In memory studies, it is a less common term, but the field's core consensus is that the act of memory is rooted in the present: ${ }^{10}$ to remember is to establish a particular position in the present by placing oneself with respect to the past. Moreover, performances of both gender and memory are socially conditioned. Existing gender norms and expectations frame the enactment of gender, and Jan and Aleida Assmann's concept of collective memory is founded on the notion, adopted from the work of Maurice Halbwachs, that all memory is socially marked: "The 
individual accrues memory only during the process of socialization."11 The central insight of recent work on gender and memory has been that memory and gender shape each other reciprocally: "Memory and gender are . . . multiply intertwined: gender is a product of cultural remembrance, is called up by memory and social practices and is constantly reinscribed into the collective memory. Memories are, moreover, gendered." 12

In their efforts to remember individuals marked by their gendered roles, Väterand Mütterliteratur are enmeshed in a complicated weave of gender, memory, and identity, as are the readers who respond to them. Understanding both the texts and the criticism that has established their boundaries thus requires asking, as Stone has suggested, "how particular ways of construing the past help to sustain social identities." ${ }^{13}$ Sylvia Paletschek and Sylvia Schraut argue that, in recent centuries, men have been the preferred objects of a European memory culture focused on politics and warfare, while women, remembered in supposedly timeless anthropological terms, remain largely invisible. This pattern of remembrance then reinforces the bourgeois gender model that segregates the public and private spheres. ${ }^{14}$

Equating Väterliteratur with second-generation cultural memory, as is frequently done, continues this pattern of viewing men's history as national history. In postwar Germany, this close association of men with the nation has permitted enactments of German identity that break decisively with the past, even as postwar society retains a core identification with German heritage. Stone writes that, in the stereotypical Väterliteratur, succeeding generations castigate and cut themselves off from "the hyper-masculine regime" of National Socialism, ${ }^{15}$ while memories of women have served a very different function. Elizabeth Heineman has shown that in the immediate postwar period, memories of women as heroic mothers and Trümmerfrauen (rubble women) were generalized to the nation, supporting the development of West German identity. ${ }^{16}$ This pattern of remembering women persists for decades in forms as diverse as literature, public sculpture, and oral interviews, offering a vision of a German people that suffered nobly and providing hope for renewal and future respectability. ${ }^{17}$ These very different functions of remembering male and female forebears begin to explain the intellectual, emotional, and identity-political stakes of second-generation Väterliteratur and Mütterliteratur and-no less importantly—of the reception that has perceived and reinforced a clear distinction between them.

Since the appearance of Väterliteratur in the 1970s, the dominant view of it has been that its second-generation authors enact a stark, often uncompromising, generational conflict. The accounts most critical of Väterliteratur, such as those of Michael Schneider and Ernestine Schlant, cast the narrators' concern with their own identities as self-serving, sometimes even pathological, and tend to associate this stance with poor aesthetic quality; Väterliteratur, they maintain, lacks self-reflexivity and linguistic sophistication..$^{18}$ Others credit the Väterliteratur with substantial self-awareness and 
success in negotiating the personal and cultural tasks of Vergangenheitsbewältigung . In this view, many of the texts' narrators reflect critically on the relationship between public and private history and try to understand their parents, even as they distance themselves from them. ${ }^{19}$ But even these studies share the fundamental diagnosis of Väterliteratur as the postwar generation's effort to distance itself critically from its fathers, and broad perceptions of Väterliteratur are heavily influenced by the more negative views. ${ }^{20}$

In contrast, studies of mother books from this era see the narrating children as simultaneously identifying with their mothers and attempting to extract themselves from the emotional and social deformations these mothers often represent. Nearly all studies focus on mother accounts by daughters and read them through the lens of gender studies, rather than of cultural memory. Patriarchal social structures, psychoanalytic concepts, or female writing practices provide the structure for their investigations of female subjectivity and relationships, while history is downplayed. ${ }^{21}$ Although individual works have sometimes been discussed within a historical framework, ${ }^{22}$ historical and political contexts are usually important not because of their implications for cultural memory or national identity, but for the way they drive constructions of gender. This focus enables feminist critique of gendered roles and social structures, but it also continues to locate memories of women in a nonpolitical realm that remains accessible as a resource for a reconstructed German identity.

Since the 1960s, the gendered dynamics of memory have contributed to a landscape in which the fathers' stories are read as the story of a nation breaking with its past, while the mothers' stories become representations of private communicative memory and the gender expectations it perpetuates. While some features of the primary texts encourage such readings, the critics' own enmeshment in gendered memory culture amplifies these tendencies and concretizes them in genre designations. When Michael Schneider discusses Väterliteratur's focus on the fathers' political history, for instance, he shifts from the term "fathers" to the gender-inclusive term "parents": "In retrospect, [the children] often saw their parents only as political subjects. . . . In so doing, they often forgot—or wanted to, or forced themselves to, forget - that these former full-fledged, halfway or even quarter Nazis were, in spite of everything, still their fathers and mothers, their uncles and aunts, their grandfathers and grandmothers." ${ }^{23}$ Though Schneider never discusses a text about a mother, his rhetorical structure constructs an equal presence for male and female relatives, transforming remembrances of fathers into the cultural memory of the nation. ${ }^{24}$ Conversely, when Claudia Mauelshagen concludes her book on Väterliteratur with a chapter about mothers, she omits any mention of National Socialism or political culture, interpreting the mother books solely within the context of feminist thought. ${ }^{25}$

Designating second-generation family writing as Väterliteratur cements a gendered landscape of memory. Astrid Erll and Klaudia Seibel write that "memory and 
gender and their multiple interdependencies are also genred, that is, largely shaped by (literary) genres." ${ }^{26}$ And genres are often gendered. Susan Figge observes that readers have frequently resisted daughter-authored Väterliteratur that violates the conventions regulating the interaction of gender, memory, and genre. ${ }^{27}$ Gender studies approaches to the Mütterliteratur that elide their historical and political content may exhibit a similar resistance-despite the fact that these mother books, like feminist-inspired historiography, aim to destabilize male-connoted cultural memory by injecting it with female experience and female-coded communicative memory, or, in Heineman's terms, by "reclaiming the civilian experience for women." ${ }^{28}$ Books about fathers and mothers have been received through the genres of Väterliteratur and the gender-oriented mother book, and these "recycled forms" ${ }^{29}$ reproduce gendered cultural memory.

\section{Ingeborg Drewitz, Gestern war heute. Hundert Jahre Gegenwart. (1978)}

Reading Mütterliteratur from the 1970s and 1980s within the framework of cultural memory breaks with this pattern. The mode of cultural memory that emerges suggests that the new family novel, too, adopts "recycled forms"-forms previously coded as female and, as such, as apolitical. I begin by discussing a novel that exemplifies the complications of making such claims. This novel, written by a member of what Weigel calls the "Hitler Youth generation," 30 has frequently been read as a reckoning with National Socialism. ${ }^{31}$ As is also the case for Christa Wolf's Kindheitsmuster (1976), however, such analyses focus primarily on the protagonist, Gabriele, so that the book is read largely in terms of self-reckoning. ${ }^{32}$

The novel encourages such a focus, since, like Kindheitsmuster, it is structured around the protagonist's life. It begins with the events surrounding Gabriele's birth, follows her experiences as a girl in the Weimar era and a young woman under National Socialism, and documents her adult struggles to balance motherhood, career, and social conscience. Gabriele's mother, Susanne, appears as one of several influential family figures in the novel, alongside Gabriele's grandmother, great-grandmother, father, grandfather, great-uncle, husband, and daughters. The novel thus treats the protagonist's broad familial inheritance and her efforts to shape this inheritance as she passes it to her children. This rendering of an extended genealogical framework and insistence on understanding the adult child as belonging to a familial history reaching into both past and future resemble the post-1990 new family writing more than paradigmatic Väterliteratur. Assmann, Holdenried, and Eigler contend that, unlike Väterliteratur, the new family novel generally incorporates several generations, including female family members, into its familial frames of reference. ${ }^{33}$ I approach Drewitz's book and others as Mütterliteratur for two reasons. First, mothers are key figures of identification and rejection, and the adult child also often struggles with 
her own role as a mother. Second, as feminist scholars of autobiography first noted in the early 1980s, writing women's lives has often entailed chronicling family members' lives; the term autobiography is a misnomer for much female life writing, in which the self can be depicted only in relationship to others. ${ }^{34}$ In a similar way, Mütterliteratur registers the individual as the recipient of multiple channels of inheritance and cultural memory. Already in its object of representation, then, the dominant practice of cultural memory in the new family writing can be viewed as having adopted a female mode of life writing and memory.

Similarly, the tendency both to acknowledge and to strain against family inheritance, remarked by feminist scholars in mother books of the 1970s and 80s, is viewed as a distinguishing characteristic of the new family writing. Assmann, Eigler, and Holdenried contend that the narrators of these novels do not sit in judgment of family members, but take an empathetic approach that allows them to integrate themselves into the family's generational chain, even as they foreground the fractures that disrupt it. ${ }^{35}$ Drewitz's novel signals the inescapable influence of the past beginning with the title: Yesterday as Today: 100 Years of the Present. The narrative structure then reproduces Gabriele's irrevocable place in the family relationships that extend from past to future. Rather than employing the narrator-centered confessional mode common in the Väterliteratur, the novel uses an extradiegetic narrator, and the opening chapters, which tell the story of Gabriele's birth, are focalized by her parents, grandparents, and great-grandmother. Her historical position and experience can be understood only as framed by what precedes them, and only by first adopting the perspectives of the relatives who shape her.

The shifts in focalization end when Gabriele reaches adolescence and the narration is locked tightly to her perspective, but a tension between identification and resistance drives the plot. As Assmann writes of the new family novel, the conflicts that set the generations against each other in the Väterliteratur are "internalized" here. ${ }^{36}$ There are two intertwined facets of this ambivalent inheritance: the performance of gender, on the one hand, and of political agency and cultural memory, on the other. About to be married, Gabriele feels a "fear of the life that mother lived, and grandmother and great-grandmother" (196), but, at least for a time, she perpetuates their pattern of existence. The long, spiraling potato peels that she produces daily, just as her grandmother and great-grandmother had done, symbolize this unbroken chain of experience. Later, she explains that she can speak of herself only in relation to her family: "every woman is I and WE at the same time" (298).

This performance of gender stands in a complicated relation to a family tradition of political resistance and humanitarian protest. The legacy begins with two men of her grandparents' generation. Her great-uncle, Paul, had been a young intellectual among the petitioning workers at Bloody Sunday in St. Petersburg in 1905 and had witnessed the protesters singing "like a great round, a human round" (26). Appearing 
from the first chapter to the last, this vignette becomes a leitmotiv that evokes the recurring "human round" of the family's social engagement. In the early years of National Socialism, her grandfather advocates for a mentally disabled boy and his mother, and during the war, Gabriele and her mother work to sustain the regime's victims by bringing them food and clothing. Up to this point, the legacy appears gender neutral. But after the war, Gabriele's husband thinks that she should abandon political and professional activity and dedicate herself to her role as wife and mother. This view drives her to separate from him and establish a career in engaged journalism, and the tension continues when they reunite and she tries to balance both parts of her life. In the fates of her daughters, the novel seems finally to suggest that the two cannot be reconciled. Her eldest daughter, Renate, forsakes her family entirely when she becomes a leader of radical protests against Vietnam and the treatment of guest workers; in contrast, her youngest daughter, Claudia, marries and has a child as a teenager.

The novel's end undermines any such certainty, however, leaving open the possibility of enacting a life that combines domestic fulfillment and political engagement. Such open-endedness is remarked in the new family writing, ${ }^{37}$ where, as here, the continuation of the family into another generation precludes closure on its past. In the novel's last pages, the narrative structure mirrors its view of history. Rather than narrating a cohesive final episode, they sketch an array of possible endings. The first several focus either on Gabriele's family life (a walk with her infant grandson, her husband's retirement party) or her career and public engagement (a final repetition of Paul's Bloody Sunday story, a visit to a journalistic source in prison). Finally, the last two combine both facets of familial inheritance. Set amidst city noises that signal the inescapable historical world, they show a perpetual dual awareness of family and social demands. In the first, Gabriele pauses in her journalistic work to look over at her grandson; in the second, Renate, encountered as she hands out flyers decrying Argentinian torture, looks at her family and nods. If there is a conclusion, it is that these two facets will continue in an uncertain coexistence.

Metanarrative consideration of how to end the story also displays the self-reflexive engagement with history that is said to characterize the "new" novels. Assmann, Eigler, and Fuchs write that these novels tend to emphasize their narrators' distance from, mediation of, and reflection on historical material. ${ }^{38}$ Such reflection on the mediation of the story takes explicit form in the novel's last section: "One could end here," the narrator notes, "or also on the Sunday . .." (381). Elsewhere, it manifests itself in the characters' memory practices and activities. In the family sphere, the memory of Great-uncle Paul at Bloody Sunday is handed down through the generations, both orally and in the original letter sent from St. Petersburg. Like the "memory icons" that prompt remembrance and "enshrine a particular version of family history" in Fuchs's account of memory contests ${ }^{39}$ the letter acts as a material link between the family's past and present. It makes its last appearance when Renate finds it while cleaning out 
her deceased grandmother's apartment and, in taking it as her physical inheritance, lays claim to the family's legacy of political resistance. Family members continually mobilize this memory to serve the needs of the present. After a Christmas celebration collapses under the weight of political and social conflict, Great-grandmother comforts the upset child Gabi by telling her about her Uncle Paul, "who was like you" (55-56). Great-grandmother's account also illustrates the selective nature of familial memory and the conflict between private and public memory to which it contributes. ${ }^{40}$ Remembering Paul as a gifted young man and thinking of what he would have done had he lived, she imagines him as an ambassador or merchant in a villa, castle, or estate; only secondarily does she think that this young protester of the Tsar might have died in WWI or become an advocate for the poor. (81)

In her work as a scholar and journalist, too, Gabriele aims to bring hidden histories to public attention and to investigate them as windows onto the present. In her dissertation, completed but not submitted in 1944, she traces National Socialism's co-opting of socialist principles and programs. Later, she writes, or tries to write, radio broadcasts that illuminate contact points of past and present: one about Berlin, long a city of conflict and controversy, and another about Prague as a home of romanticism, a safe haven for Berliners during the Napoleonic wars, and a city repressed after the Prague Spring. As it depicts the way that Gabriele and her family remember their family and nation, Drewitz's book reflects on the constructions of history that weave together past and present. ${ }^{41}$

Once again, the book's structure mirrors its conceptual understanding. Five italicized sections entitled "From the working notes for the novel" interrupt the main narrative at intervals. These passages do not reveal the narrative's evolution or differ substantially in narrative perspective; instead, they fill gaps in the main narrative in much the same narrative voice. This similarity between "working notes" and "finished text" suggests that the entire novel is a work of processing. The last of these "working notes" reflects explicitly on how experience yields memory and historical narrative. In scribbled notes and fragmentary statements caught on microphone, Gabriele tries to capture sensory impressions, "to organize the images surging across her retina, the confusion of words making a ruckus in her ears" (359). These sentences are all we have, Gabriele thinks - but they can never really be trusted. As it tells its story of five generations, the novel ponders the relationships between history, memory, narrative, and gender. This mother book of the 1970s thus does what the new family novels are said to do: supplement its literary qualities with a contribution to discourses and theories of memory, narrative, and history. ${ }^{42}$

\section{Barbara Bronnen, Die Tochter (1980)}

This engagement is still more explicit in Barbara Bronnen's Die Tochter. The novel resembles paradigmatic Väterliteratur in many respects. Presented as fictional, its characters correspond closely to the biographical author and her parents, the 
playwright Arnolt Bronnen and his second wife, Hildegard von Losso. In prototypical Väterliteratur fashion, the protagonist, Katharina, sets out after her father's death to learn about and reckon with his actions during the Third Reich. She wrestles with the conflicting emotions called forth by her childhood adulation of her father, his collusion with National Socialism and corresponding determination to blot out his Jewish background, his transformation into a Communist leader, his abandonment of his family, and his position as privileged author in East Germany.

Beginning with the title, however, this book signals the daughter and her pursuit of history as its primary concern. Moreover, Katharina is emphatically her mother's daughter as much as her father's, and the book deals equally with the legacy of both figures. ${ }^{43}$ The first two sections narrate Katharina's daily life as an author and single mother in the late 1970s, exploring her struggles to balance the demands of career and family, manage her relationships with men, and negotiate the sometimes treacherous terrain of her tight-knit female family unit comprising mother, grandmother, and sister. The third section then relates Katharina's pursuit of her father's history. In the fourth section, two chapters set in the present bookend two chapters in which Katharina delves, finally, into her mother's experience of the past. The majority of the book, then, follows the conflicts of Katharina's adult life and posits them-from her ambivalent feelings toward monogamy to her self-doubt about her political commitments - as rooted in the residues of the past that continue to shape her and inhabit her world. Her investigation of the past is motivated explicitly by her desire to navigate the relationships and demands of the present. The parallel explorations of her father's and mother's histories offer the chance to compare how enactments of gender shape the processes and products of cultural memory, and how cultural memory perpetuates and influences the enactment of gender.

Fuchs calls recent family novels memory contests, and Assmann, Eigler, and Holdenried all see clashes between competing histories as a central feature of the genre. These novels confront the tensions between familial and public histories and ruminate on the ways in which knowledge won about the past in one sphere may enrich the histories related in the other. ${ }^{44}$ They also highlight the conflict between established, calcified versions of history and the hidden stories they suppress, and between histories consisting largely of silences and taboos and those intent on articulating what Assmann calls non-dits. ${ }^{45}$ Katharina's impulse to explore the past arises when she receives a letter from her mother and realizes how little she knows about her life. The letter and Katharina's reaction to it show that she has resisted this knowledge because of its implications for her own self-understanding: "there was an inner voice that had always ordered her 'Halt!' when she came too close to [imagining her mother's inner life], as if she was afraid she would look too deeply into herself if she did" (66). Katharina resolves to end the silence, but she comes to her mother's history only after exploring her father's. 
She begins this exploration because she is dissatisfied with the silences of public history. Receiving a commission to write a play about her father, she begins by consulting an encyclopedia entry and her father's autobiography. These accounts leave her frustrated because they do not capture her father or his life adequately; they fail to penetrate his many "disguises" and barely register her mother's existence (121). Confronted with this public persona, she undertakes a journey to visit the places and people of his life. Significant parts of his history also emerge from Katharina's own memory, and recollections of painful and formative episodes in her own life, notably her relationship with her ex-husband, punctuate her reconstruction of her father's. This reconstruction thus appears as grounded in and affected by her own experience. Her journey yields a personal history that, while similar to the public history in its facts, both reveals the depths of her father's destructiveness and salvages a constructive energy that she hopes to emulate (193). Her father is no longer a "clichéd myth," but an individual to whom she is multiply tied (194).

Katharina then returns to the project of learning about her mother's past, which has been doubly obstructed by the gendered dynamics of memory. There is no public record to pursue, for, like countless other women, Ada appears unimportant to the memory of the nation. The novel also suggests, however, that women's frequent role as the subjects of memory - as those tasked with the work of remembering a painful past - prevents them from becoming its objects. ${ }^{46}$ In a sequence that hovers between dream and reality, Katharina says goodbye to her mother to go search for her father: "At Ada's, Katharina became light-headed [hell im Hirn] and nearly blacked out as she thought: Maybe I should have done this long ago, put something between us, flee the oversight she has had of Father even in death, see Father with my own eyes, not with Mother's, and with that see her anew" (163). The description of Katharina as "hell im Hirn" suggests both dizziness and enlightenment as she realizes that breaking through her mother's control of her father's memory might change her vision of both parents. Indeed, it is only when Katharina returns from her father quest that she can begin to pursue her mother's past. The barriers to remembering the maternal figure are different: rather than the conflict between public and private memory that obstructs her view of her father, Katharina must overcome a personal resistance born of memory's uncomfortable relevance for her own life and a gendered division of memory work.

Her mode of investigating her mother's past also differs starkly. Unlike the fathers of prototypical Väterliteratur, her mother is still alive. Rather than perusing old documents or interviewing acquaintances, then, Katharina speaks with her mother, perpetuating remembrance through a female line of communicative memory. But, self-reflexive as the novel is in exposing memory's gendered terrain, it seems blind to the way that the postwar narrative of innocent German women sustaining the nation structures Katharina's perception. During their conversation, Katharina's initially critical stance toward Ada's wartime activities yields to empathy and a 
recognition of what she endured. She opens the dialogue with accusatory questions regarding Ada's employment in the National Socialist Reichsfunk and cultural and press agencies. "So you went along with it [mitgemacht]," she states and, prompting Ada to continue, asks: "Yes, Mother, what did you do . . . what did you do with your knowledge?" (216-217). Here, she views and criticizes Ada as a historical agent. Ada responds by lamenting Katharina's coldness and insisting that all she ever wanted was her family and their well-being. Katharina then softens her tone and attributes her mother's choices to emotion and a lack of rational comprehension of the historical situation, characteristics long marked as female: "You had too much heart and too little understanding, Mother" (219). In the end, she accepts Ada's perspective, situating her in opposition to men and the country they controlled: "Tell me more, Mother, about Father and the Vaterland" (220). ${ }^{47}$ In the eleven pages that follow, Ada gives an uninterrupted account of the hardships she experienced while trying to sustain her family during the war and of the almost unbearable demands made by her husband and the historical situation.

This move to understand distasteful wartime sentiments and activities by acknowledging private and emotional motivations appears in other mother accounts, too; in Peter Handke's Wunschloses Unglück (A Sorrow Beyond Dreams), for instance, the narrator ascribes the mother's enthusiasm for National Socialism to the emotional excitement it provided and interprets the era's significance to his mother as personal, rather than political. ${ }^{48}$ The mode of remembrance and interpretation in these mother narratives is based on the gendered assumption that, for women, feeling and domestic concerns are paramount. A similar dynamic is at work in the new family writing, without being so markedly gendered; there, private stories challenge a public history of condemnation by providing the foundation for empathy with male and female family members. The "female" mode of remembrance spills over to the treatment of male family members in the Mütterliteratur, too; Drewitz's novel represents Gabriele's father's opportunistic membership in the National Socialist Party as the product of the bitter disappointment and loss of self-worth his unemployment causes, and Katharina recognizes that her father possessed an admirable willingness to question himself and to begin anew. In these books, memory within and about the female line seems to affect memory practices as a whole. ${ }^{49}$ Such memory is not without tension or criticism. As in the new family writing, it remains a contest that can never be entirely reconciled. At the end of Ada and Katharina's conversation, Ada pushes back against her daughter's questions with one of her own: "what is it when you write: vivisection, robbery, murder?" (230). Still, the possibility of empathy, rooted in selfreflexivity and an awareness of the performative nature of memory, underlies many books that remember mothers. This kind of remembrance opens the door, perhaps, to a memory practice that remembers men differently, too- the kind associated with third-generation writing. 


\section{Helga Novak, Die Eisheiligen (1989)}

The bitter recriminations of Helga Novak's Die Eisheiligen (1989) seem not to fit this "female" mode of remembrance at all, but to take the accusatory stance associated with Väterliteratur. ${ }^{50}$ The narrator's status as an adopted child, biologically severed from the parents who raise her, is an analogue to her relationship with her mother, which has been severed by the lack of any positive emotion. The narrator refers to her mother as Kaltesophie, a name that recalls many of the character and parenting traits ascribed to the fathers of the paradigmatic Väterliteratur: she is emotionally distant, harshly disciplinary, and verbally abusive. As in such father books, the child eventually takes a political stance that opposes her parents'-she embraces East German socialism against her parents' monarchism-and then divorces herself from them entirely by having herself designated an orphan so she can receive a scholarship to a party boarding school.

For all its reviling of the mother, however, the book shows an excruciating awareness that the daughter reenacts Kaltesophie's patterns of behavior. This awareness manifests itself in part in a linguistic self-reflexivity that is sometimes viewed as lacking in the Väterliteratur, ${ }^{51}$ but that is noted as a constitutive feature of the new family writing. ${ }^{52}$ The first section of the book establishes language as the daughter's refuge, the space where she can assert her own identity and resist the mother's unrelenting attempts at human dressage. Shortly after she learns to write her name, a bank teller acknowledges her by calling her "young lady" and asking her to sign a deposit slip. "I still saw myself as unimportant [schrieb mich klein]" the narrator admits about her cowed younger self, "but I wrote my name" (23). At school and at home, castigated and corrected at every turn, she scratches her name into furniture, windowsills, and any other surface she can find (25, 35-36). Later, she begins to write and hide voluminous journals and poetry that allow her a space of freedom and that retaliate secretly against her mother's cruelty and denigration.

The novel shows that the daughter's rebellious language is intimately derived from the mother's repressive one, however. The book's early pages are peppered with passages of free verse that reproduce the mother's abusive tirades and the Prussian values they are meant to impart. The visually striking form suggests the rhetorical and emotional weight of these rebukes, which take place during routine activities such as meals or comportment lessons. The mother demands that the girl demonstrate her submission to these litanies by repeating them: "will you now be / good / compliant / docile / obedient / grateful / industrious / yes yes yes yes yes / . . I promise to be / good / compliant / docile / obedient / grateful / industrious . . . from now on / I will behave" (26). Later, blocks of free verse expressing the narrator's fears, insecurities, and obsessions show that she still inhabits her mother's restrictive language; the truncated, left-aligned phrases and the large white spaces on the right half of the page highlight the narrow realm of her own existence. These passages also reveal that 
she has internalized her mother's venomous violence. Considering various sources of poison she could use against her mother or herself, she asks "a question: is the poison in the blooms / or the bulbs. / I take what I have. / Collect, crack, dry, grind cherry pits / bitter flour for you or for me" (140). This perpetuation of the mother's repression and aggression recognizes, as much as any post-Wall example of family writing, that old wounds and conflicts are passed down through generations. The reckoning with the family past never yields closure. The final scene, which narrates the daughter's arrival at her new boarding school, shows that her new situation will be just as repressive as the family home. The school's bucolic loveliness is deceptive, for the last sentence notes that "shards of glass were cemented on top of the wall" (362). These broken pieces of glass betray the dangerous side of the new Socialist order, but they also evoke shards of ice symbolic of the mother's fatal coldness. While the mother's birthday, May 15, may make her the "last of the ice saints" (330), the novel drives toward the recognition that she is not the last. The language, conclusion, and title-the plural Die Eisheiligen — show that her psychological and emotional deformation continue in her daughter.

\section{Gender, Experience, and Memory}

Gendered memory practices are not the sole cause of the differences in postwar narratives about mothers and fathers, of course. Men's and women's experiences and roles in the phenomenon of National Socialism were different, and their children had different relationships with the mothers who parented them during the war than with the fathers who were absent for months or years at a time. To a large degree, gendered patterns of memory reflect these divergent experiences. As I hope this essay has shown, however, they also amplify them.

Memories of civilian suffering provide a final example of this phenomenon. With much of the male population in the army, civilian suffering was a disproportionately female experience, so it is not surprising that paradigmatic Väterliteratur focuses on fathers' culpability, while the Mütterliteratur tends to mark the war era as a time of suffering and endurance. But such representations also reenact long traditions of gendered memory as they reproduce broad postwar memory trends. In identifying women as frequent agents of memory, Assmann claims that they assume the potentially crippling weight of remembering suffering and pain..$^{53}$ As objects of memory, too, women are more likely to be associated with suffering. In the postwar era, as in other times, a resistance to remembering men as victims was fueled both by the desire to avoid exonerating men for the suffering they caused as soldiers and political agents and by a reluctance to see men as vulnerable to violence and injury. ${ }^{54}$

The depiction of civilian suffering is, perhaps, the most universal trait of the Mütterliteratur. Mothers at all points on the political spectrum suffer, from those embroiled with the National Socialist regime to those who fear persecution at 
its hands. Novak's novel, for example, details the strains of evacuation to the countryside, contains a graphic sequence on a bombing raid, and relates the strategies used to evade rape by Russian soldiers and the fates of those who escape sexual violence and those who do not. In Die Tochter, Katharina's empathy for her mother grows as she confronts the realities of her mother's wartime life, during which she bore the brunt of ensuring survival for herself, her children, and her selfish and impractical husband. The novel tells of bombings in Berlin, the family's flight from the city, Ada's efforts to secure bread, eggs, and other foodstuffs, and the recurring need to protect or rescue her husband from the authorities. Gestern war heute renders wartime and postwar conditions in detail: hunger and queueing, the hysteria and stench of the bomb shelters, the collapse of infrastructure and the thirst and darkness that follow, and the deaths of infants, children, and old people in the frigid winter of 1945-1946. A stylistic shift marks these descriptions. In most of the novel, extensive evocations of Gabriele's thoughts and feelings heighten the novel's focalization through her. Here, that interiority frequently disappears, so that the chapters describing the end of the war offer a generalized, sober report of events as pages go by without mention of Gabriele or her family. (143, 148-156) The novel oscillates between representing its characters' suffering; recording others' horrors, as when Gabriele exits a bomb shelter to find a mother holding the corpses of her four children; and taking an impersonal stance. Perhaps reflective of Gabriele's own numbness during Germany's collapse, the effect of these passages is also to make the suffering not Gabriele's, but that of Germans. In representing widespread German suffering, the Mütterliteratur enacts a female-coded memory perhaps inaccessible to the Väterliteratur. Again, such recognition of suffering by victims, perpetrators, and bystanders also defines the new family writing, which is seen to explore how trauma perpetuates itself, or "telescopes," across generations. ${ }^{55}$ Reading the Mütterliteratur in the context of history and cultural memory thus helps to refute the notion that high-profile works from the post-1990 era, notably W.G. Sebald's Luftkrieg und Literatur (On the Natural History of Destruction) (lectures 1997, publication 1999) and Günter Grass's Im Krebsgang (Crabwalk) (2002), broke a taboo regarding the representation of German suffering. ${ }^{56}$

To view books about mothers as precursors to recent family writing is not to argue that they anticipate positive developments in memory culture or that they are superior to a monolithic Väterliteratur. Rather, it suggests a new genealogy for recent attempts at literary Vergangenheitsbewältigung and helps us to understand why common views of Väterliteratur and generational descriptions of memory culture have been so persistent—why secondary accounts like Brandstädter's and father books like Peter Henisch's Die kleine Figur meines Vaters (Negatives of my Father), which also exhibits many features of the new family writing, have not been able to dispel the generational model. Gendered memory norms have encouraged screening out supposedly anomalous elements and texts, because, as Astrid Erll emphasizes, literary 
texts can enter and transform cultural memory only when they align sufficiently with its existing structures for comprehending the past. ${ }^{57}$ The continuities emphasized in the mother books violate the gendered conventions of cultural memory, construed as male memory, that dominated the later postwar period. In fact, they violate a far longer tradition. As Susan Figge points out, paradigmatic Väterliteratur enacts a father-son conflict long familiar in German literature, in which the familial contest appears as "paradigmatic for the struggles essential to self-definition and to social, political, and cultural change." ${ }^{58}$ For decades, this narrative of independence and the rejection of tradition served German society's psychological, social, and political needs far better than the narratives of familial connection and influence long associated with female experience and writing. The kind of memory represented by the new family writing has gained prominence recently, not only because of the passage of generations, but also because of a shift in the space of possibility for enacting gendered cultural memory. As was the case immediately after the war, female experience and female-connoted memory practices are serving the needs of a nation reestablishing its identity and the stories that support it.

\section{Notes}

I would like to thank May Mergenthaler, Eva Revesz, Sabine Hake, and the anonymous reviewers for their helpful suggestions.

1. Sigrid Weigel, “'Generation' as a Symbolic Form: On the Genealogical Discourse of Memory since 1945," Germanic Review 77, no. 4 (2002): 270.

2. Ernestine Schlant, The Language of Silence: West German Literature and the Holocaust (New York: Routledge, 1999). 88.

3. Michael Schneider and Jamie Owen Daniel, "Fathers and Sons, Retrospectively: The Damaged Relationship between Two Generations," New German Critique 31(1984): 43.

4. Anne Fuchs, "From 'Vergangenheitsbewältigung' to Generational Memory Contests in Günter Grass, Monika Maron and Uwe Timm," German Life and Letters 59, no. 2 (2006): 181.

5. Aleida Assmann, "Limits of Understanding: Generational Identities in Recent German Memory Literature," in Victims and Perpetrators: 1933-1945: (Re)Presenting the Past in Post-Unification Culture, ed. Laurel Cohen-Pfister and Dagmar Wienroeder-Skinner, Interdisciplinary German Cultural Studies (IGCS) 2 (Berlin: De Gruyter, 2006); Friederike Eigler, Gedächtnis und Geschichte in Generationenromanen seit der Wende (Berlin: Erich Schmidt, 2005); Michaela Holdenried, "Zum aktuellen Familienroman als erinnender Rekonstruktion," Le Texte Étranger 8 (2011).

6. Mathias Brandstädter, Folgeschäden: Kontext, narrative Strukturen und Verlaufsformen der Väterliteratur 1960 bis 2008 (Würzburg: Königshausen \& Neumann, 2010). 125-154; Julian Reidy, Rekonstruktion und Entheroisierung: Paradigmen des 'Generationenromans' in der deutschsprachigen Gegenwartsliteratur (Bielefeld: Aisthesis, 2013), 21-37.

7. Caroline Schaumann, Memory Matters: Generational Responses to Germany's Nazi Past in Recent Women's Literature (Berlin: Walter de Gruyter, 2008), 1-23. Here, 10.

8. Ingeborg Drewitz, Gestern war heute. Hundert Jahren Gegenwart (Düsseldorf: Claassen, 1978); Barbara Bronnen, Die Tochter (Munich: dtv, 1982); Helga Novak, Die Eisheiligen (Frankfurt am Main: Luchterhand, 1989). Translations from these texts are my own. Other books in the body of historically inflected mother books are Peter Handke, Wunschloses Unglück (1974); Karin Struck, Die Mutter (1975); Christa Wolf, Kindheitsmuster (1976); Hans Frick, Die blaue 
Stunde (1977); Katja Behrens, Die dreizehnte Fee (1983); Hanns-Josef Ortheil, Hecke (1983); Waltraud Anna Mitgutsch, Die Züchtigung (1985); Verena Stefan, Es ist reich gewesen: Bericht vom Sterben meiner Mutter (1993). Helma Sanders-Brahms's film Deutschland, bleiche Mutter (1980) can be seen as a comparable "mother film."

9. Meike Penkwitt, "Einleitung," Freiburger FrauenStudien 19 (2006): 6-7. Katherine Stone, "The Pitfalls of Constructing a Female Genealogy: Cultural Memory of National Socialism in Recent Family Narratives," in German Women's Writing in the Twenty-First Century, ed. Hester Baer and Alexandra Merley Hill (Rochester, NY: Camden House, 2015), 56, 66.

10. See Astrid Erll, Kollektives Gedächtnis und Erinnerungskulturen: Eine Einführung, 2nd ed. (Stuttgart: J.B. Metzler, 2011), 7.

11. Jan Assmann, Das kulturelle Gedächtnis: Schrift, Erinnerung und politische Identität in frühen Hochkulturen (Munich: C.H. Beck, 1997), 35.

12. Penkwitt, "Einleitung," 1. Translation from Sylvia Paletschek and Sylvia Schraut, "Introduction: Gender and Memory Culture in Europe," in The Gender of Memory: Cultures of Remembrance in Nineteenth- and Twentieth-Century Europe (Frankfurt am Main: Campus, 2008), 10.

13. Katherine Mary Stone, "Gender and German Memory Cultures: Representations of National Socialism in Post-1945 Women's Writing” (PhD diss., Cambridge University, 2014), 12.

14. Paletschek and Schraut, "Remembrance and Gender: Making Gender Visible and Inscribing Women into Memory Culture," 267, 70.

15. Stone, "Gender and German Memory Cultures: Representations of National Socialism in post1945 Women's Writing," 115-131, here 36.

16. Elizabeth Heineman, "The Hour of the Woman: Memories of Germany's 'Crisis Years' and West German National Identity,” American Historial Review 101, no. 2 (1996): 354-395.

17. Stone, "Gender and German Memory Cultures," 22-35; Sigrid Weigel, "Der Ort von Frauen im Gedächtnis des Holocaust: Symbolisierungen, Zeugenschaft und kollektive Identität," Sprache im technischen Zeitalter 135 (1995); Margit Reiter, Die Generation danach: Der Nationalsozialismus im Familiengedächtnis (Innsbruck: Studien, 2006). 233-236.

18. Schneider, "Fathers and Sons, Retrospectively." Schlant, Language of Silence: 83-96.

19. See Jochen Vogt, "Er fehlt, er fehlte, er hat gefehlt: Ein Rückblick auf die sogenannten Väterbücher," in Deutsche Nachkriegsliteratur und der Holocaust, ed. Stephan Braese et al. (Frankfurt am Main: Campus, 1998); Claudia Mauelshagen, Der Schatten des Vaters: Deutschsprachige Väterliteratur der siebziger und achtziger Jahre (Frankfurt am Main: Peter Lang, 1995), 302; Ralph Gehrke, Literarische Spurensuche: Elternbilder im Schatten der NS-Vergangenheit (Opladen: Westdeutscher Verlag, 1992). 272-276; Anne Fuchs, "The Tinderbox of Memory: Generation and Masculinity in Väterliteratur by Christoph Meckel, Uwe Timm, Ulla Hahn, and Dagmar Leupold," in German Memory Contests: The Quest for Identity in Literature, Film, and Discourse since 1990, ed. Anne Fuchs, Mary Cosgrove, and George Grote (Rochester, NY: Camden House, 2006); Barbara Kosta, "Väterliteratur, Masculinity, and History: The Melancholic Texts of the 1980s," in Conceptions of Postwar German Masculinity, ed. Roy Jerome (Albany, NY: State University of New York Press, 2001).

20. Some accounts of third-generation writing, for instance, define it against the stereotypical view of Väterliteratur. While Fuchs acknowledges more differentiated accounts, her comparisons seem to refer to the more polemical treatments. See "From 'Vergangenheitsbewältigung.'” In other places, this reliance is explicit. See Friederike Eigler, Gedächtnis und Geschichte in Generationenromanen seit der Wende (Berlin: Erich Schmidt, 2005), 25.

21. See Katharina Aulls, Verbunden und gebunden: Mutter-Tochter-Beziehungen in sechs Romanen der siebziger und achtizger Jahre (Frankfurt am Main: Peter Lang, 1993); Barbara Kosta, "Muttertrauma: Anerzogener Masochismus," in Mütter-Töchter-Frauen: Weiblichkeitsbilder in der Literatur, ed. Helga Kraft and Elke Liebs (Stuttgart: J.B. Metzler, 1993); Helga Kraft and Barbara Kosta, "Das Angstbild der Mutter: Versuchte und verworfene Selbstentwürfe,” in Kraft 
and Liebs, Mütter-Töchter-Frauen; Mauelshagen, Schatten des Vaters: 261-284; Susanne Lackner, Zwischen Muttermord und Muttersehnsucht (Würzburg: Königshausen \& Neumann, 2003), 15-16.

22. Most of these "exceptions" are books by male authors (Peter Handke's Wunschloses Unglück, Hanns-Josef Ortheil's Hecke) or books that focus on the daughter's life and relationship to National Socialism (Drewitz's Gestern war heute, and Wolf's Kindheitsmuster). Erin McGlothlin draws attention to the importance of supposedly marginal mother figures in father books. Erin McGlothlin, Second Generation Holocaust Literature: Legacies of Survival and Perpetration (Rochester, NY: Camden House, 2006). 180-198.

23. Schneider, "Fathers and Sons," 12.

24. Schlant devotes one paragraph to representations of mothers and discusses differences between sons' and daughters' father narratives, but her terminology shows the same slippage. Schlant, Language of Silence, 85, 87-88.

25. Mauelshagen, Schatten des Vaters: 261-284.

26. Astrid Erll and Klaudia Seibel, "Gattungen, Formtraditionen und kulturelles Gedächtnis," in Erzähltextanalyse und Gender Studies, ed. Ansgar Nünning and Vera Nünning (Stuttgart: J.B. Metzler, 2004), 180.

27. Susan G. Figge, "Fathers, Daughters, and the Nazi Past: Father Literature and Its (Resisting) Readers," in Gender, Patriarchy, and Fascism in the Third Reich: The Response of Women Writers, ed. Elaine Martin (Detroit: Wayne State University Press, 1993).

28. For examples of postwar German historiography, see Reiter, Generation danach. Margarete Dörr, "Wer die Zeit nicht miterlebt hat . . ." Frauenerfahrungen im Zweiten Weltkrieg und in den Jahren danach, 3 vols. (Frankfurt am Main: Campus, 1998). Heineman, "Hour of the Woman,” 389

29. Erll and Seibel, " Gattungen, Formtraditionen und kulturelles Gedächtnis,” 190.

30. Weigel, "Generation," 272-275.

31. See Gudrun Loster-Schneider, "Unscharfe Bilder?: Krieg und Gedächtnis in deutschen Generationenromanen," in Krieg und Gedächtnis. Ein Ausnahmezustand im Spannungsfeld kultureller Sinnkonstruktionen, ed. Lars Koch (Würzburg: Königshausen \& Neumann, 2005): 241-265; Michelle Mattson, Mapping Morality in Postwar German Women's Fiction (Rochester, NY: Camden House, 2010); Margaret E. Ward, "Ingeborg Drewitz: Three Generations of Women Respond to Fascism," in Facing Fascism and Confronting the Past: German Women Writers from Weimar to the Present, ed. Elke P. Frederiksen and Martha Kaarsberg Wallach (Albany, NY: State University of New York Press, 2000). Gender-oriented readings include Aulls, Verbunden und gebunden: 114-138; Helga Kraft, "Zwischen Traditionalismus und Fortschritt: Frauengenerationen im Werk Ingeborg Drewitz,'” in "Von der Unzerstörbarkeit des Menschen”: Ingeborg Drewitz im literarischen und politischen Feld der 50er bis 80er Jahre, ed. Barbara Becker-Cantarino and Inge Stephan (Bern: Peter Lang, 2005).

32. Margaret Ward connects analysis of mother-daughter relationships and of character responses to National Socialism, but focuses primarily on the protagonist's role as mother. Ward, "Ingeborg Drewitz."

33. Assmann, "Limits of Understanding," 34; Holdenried, "Zum aktuellen Familienroman”; Eigler, Gedächtnis und Geschichte, 25.

34. See Mary G. Mason, "The Other Voice: Autobiographies of Women Writers," in Autobiography: Essays Theoretical and Critical, ed. James Olney (Princeton, NJ: Princeton University Press, 1980); Domna Stanton, "Autogynography: Is the Subject Different?," in The Female Autograph: Theory and Practice of Autobiography from the Tenth to the Twentieth Century, ed. Domna Stanton (Chicago: University of Chicago Press, 1987); Susan Stanford Friedman, "Women's Autobiographical Selves: Theory and Practice," in The Private Self: Theory and Practice of Women's Autobiographical Writings, ed. Shari Benstock (Chapel Hill: University of North Carolina Press, 1988). 
35. Assmann 33-34, "Limits of Understanding"; Eigler, Gedächtnis und Geschichte, 25-26; Holdenried, "Zum aktuellen Familienroman."

36. Assmann, "Limits of Understanding," 47.

37. Eigler, Gedächtnis und Geschichte, 60; Fuchs, "From 'Vergangenheitsbewältigung,"” 179.

38. Assmann, "Limits of Understanding," 34; Eigler, Gedächtnis und Geschichte, 25-26; Fuchs, "From 'Vergangenheitsbewältigung," 179.

39. Fuchs, "From 'Vergangenheitsbewältigung,"” 184. See also Eigler, Gedächtnis und Geschichte, 26.

40. Assmann, "Limits of Understanding," 32-33; Eigler, Gedächtnis und Geschichte, 36; Holdenried, "Zum aktuellen Familienroman."

41. Assmann 33-34; Eigler, Gedächtnis und Geschichte, 25-26; Fuchs 181.

42. Eigler, Gedächtnis und Geschichte, 26, 61; Fuchs, "From 'Vergangenheitsbewältigung,"” 181.

43. Interestingly, Susan Figge's excellent article on gender bias and Väterliteratur does not address the novel's reckoning with the mother. Figge, "Fathers, Daughters."

44. Assmann, "Limits of Understanding," 32-33; Eigler, Gedächtnis und Geschichte, 36; Holdenried, "Zum aktuellen Familienroman."

45. Assmann, "Limits of Understanding," 33; Eigler, Gedächtnis und Geschichte, 62; Fuchs, "From 'Vergangenheitsbewältigung,"” 186; Holdenried, "Zum aktuellen Familienroman."

46. Aleida Assmann posits that in the gendered division of memory work, men appear as memory's objects and women as its subjects. Aleida Assmann, "Geschlecht und kulturelles Gedächtnis," Freiburger FrauenStudien 19 (2006).

47. Ralph Gehrke offers a similar analysis. Gehrke, Literarische Spurensuche, 194-197.

48. See Katra A. Byram, Ethics and the Dynamic Observer Narrator: Reckoning with Past and Present in German Literature (Columbus: Ohio State University Press, 2015). 175-177.

49. Gehrke notes (critically) Katharina's identification with both parents. Gehrke, Literarische Spurensuche: 198-201.

50. On the negative tone of this relationship, see the gender-oriented Aulls, Verbunden und gebunden; Kraft and Kosta, "Das Angstbild der Mutter: Versuchte und verworfene Selbstentwürfe."

51. See Schlant, Language of Silence: 92-93; Hinrich C. Seeba, "Erfundene Vergangenheit: Zur Fiktionalität historischer Identitätsbildung in den Väter-Geschichten der Gegenwart," Germanic Review 66, no. 4 (1991).

52. Eigler, Gedächtnis Und Geschichte, 26.

53. Assmann, "Geschlecht und kulturelles Gedächtnis," 30-36.

54. On the "Verletzungsoffenheit" of men, see Hans-Joachim Lenz, "Männer und die Widerfahrnisse des Krieges," Freiburger FrauenStudien 20 (2007).

55. Fuchs, "From 'Vergangenheitsbewältigung,"” 183-184; Holdenried, "Zum Aktuellen Familienroman"; Stuart Taberner and Karina Berger, "Introduction," in Germans as Victims in the Literary Fiction of the Berlin Republic, (Rochester, NY: Camden House, 2009).

56. Efforts to debunk the idea of a taboo rarely cite books about mothers. Stuart Taberner and Karina Berger, for example, cite only Wolf's Kindheitsmuster. See "Introduction," 5-7. For a summary of responses to Sebald, see Volker Hage, Zeugen der Zerstörung. Die Literaten und der Luftkrieg (Frankfurt am Main: Fischer, 2003), 118-124.

57. Erll, Kollektives Gedächtnis, 183-199.

58. Figge, "Fathers, Daughters," 275-276. 